\title{
Comparing Suitable Habitat Models to Predict Rare and Endemic Plant Species Distributions: What are the Limits of the Niche of Cola lorougnonis (Malvaceae) in Côte d'Ivoire?
}

\author{
Bi Tra Aimé Vroh ${ }^{1}$, Constant Yves Adou Yao ${ }^{1,2}$, Kouassi Bruno Kpangui ${ }^{3}$, Zoro Bertin Goné Bi ${ }^{1,2}$, Djaha Kouamé , \\ Kouao Jean Koffi ${ }^{4}$, Béné Jean Claude Koffi ${ }^{3} \&$ Kouakou Edouard N'Guessan ${ }^{1}$ \\ ${ }^{1}$ Université Félix Houphouët-Boigny, UFR Biosciences, Laboratoire de Botanique, Côte d'Ivoire \\ ${ }^{2}$ Centre Suisse de Recherche Scientifique en Côte d'Ivoire, Côte d'Ivoire \\ ${ }^{3}$ Université Jean Lourougnon Guédé; UFR Environnement, Côte d'Ivoire \\ ${ }^{4}$ Université Nangui Abrogoua; UFR Sciences de la Nature; Unité de recherche Ecologie et biodiversité, Côte \\ d'Ivoire \\ Correspondence: Bi Tra Aimé Vroh, Université Félix Houphouët-Boigny, UFR Biosciences, Laboratoire de \\ Botanique, Côte d'Ivoire. E-mail: vrohbitra@gmail.com
}

Received: June 14, 2016 Accepted: June 22, 2016 Online Published: June 27, 2016

doi:10.5539/enrr.v6n3p1 URL: http://dx.doi.org/10.5539/enrr.v6n3p1

\begin{abstract}
Cola lorougnonis is an endemic, rare, and treated species. It was recently recorded in Dékpa forest near Agbaou (a village of Divo region, Côte d'Ivoire). In the same forest, 20 other rare and endemic plant species were recorded. Accurate modeling of geographical distributions of these species is crucial to various applications in ecology and biodiversity conservation. The present study analyzed suitable habitat models for the 21 species. The main objective was to test geographical predictions for the focused species: Cola lorougnonis. We used Maxent modelling method for predicting potential suitable habitats combining environmental variables and species records. We evaluated Maxent predictions using the area under the receiver-operating characteristic curve (AUC). For each species, the map of distribution was engineered using DIVA-GIS. We compared the suitable habitat areas among species. Principal Canonical Analysis allowed the ordination of species according to environmental variables. AUC values allowed to get 11 species with excellent distribution models, 8 species with good distribution models, and 2 species with predictive models considered as acceptable. Cola lorougnonis $(\mathrm{AUC}=0.99)$ and Drypetes singroboensis $(\mathrm{AUC}=0.96)$ have the same focused area: moist semi-deciduous forest in Côte d'Ivoire. They are more sensitive to changes in rainfall of both warmest and coldest seasons. The State of Côte d'Ivoire has to undertake monitoring, assessment and reporting of conservation status facilitation for all habitats where these species could be found within the territory. Additional studies focusing on the investigation areas and niche models onto future conditions of climate could be considered.
\end{abstract}

Keywords: rare species, Maxent model, climate change, biodiversity conservation, tropical forest

\section{Introduction}

Tropical forests house the most tree species diversity around the world (Poorter et al., 2004; Sheil et al., 2004; Schroeder et al., 2010; Slik et al., 2015). These forests harbour some of the highest levels of biodiversity on earth as well as the largest number of species threatened, rare and endemic with global extinction (Parmentier et al., 2007). However, over the last decade, human-impacted ecosystems including agriculture and extractive activities played a crucial role in land degradation (Vroh et al., 2015), species extinction and climate changes (Ghazoul \& Sheil, 2010). Species extinction and climate change are two important components on global change. These two components degrade the quality of both environment and human well-being. If these phenomena are considered normal during a long time, they are often exacerbated by human pressure. Today, in international negotiations, interest has increased particularly to find global strategies to induce biodiversity conservation (Scheldeman \& van Zonneveld, 2012) in tropical forests. Among these strategies, biodiversity offset is the first and most important step in the mitigation hierarchy (International Union for Conservation of Nature [IUCN], 2015a). 
In Côte d'Ivoire, Cola lorougnonis (Figure 1) was recorded for the first time in 1957 by the botanist Aké-Assi, in a forest near the city of Divo, in the Centre-west of the Country. The latest record of this species was in the same forest area in 1972 but geographical coordinates were not noted (Aké-Assi, 2001-2002). Specimens of Cola lorougnonis were deposited in international herbaria including the Museum of Natural History of Paris. In the 1980s, the introduction of cocoa culture in Divo region resulted in the degradation of forests, the main habitat of Cola lorougnonis. Since the species was locally regarded as disappeared from Ivorian natural flora and recorded as Endanger species on the IUCN redlist (1994).

In 2008 and 2011, during an environmental and social survey of mining activities, we recorded Cola lorougnonis in Dékpa forest of Agbaou village (Department of Divo). However, this forest is located in a mining perimeter of gold and must be destroyed during the extraction. As Ivorian legislation does nothing in terms of biodiversity offset, talks were undertaken with the mining company to save this forest from mining activities. With the mining society and local community from five surrounding villages, we created a conservation area for biodiversity offset, named "Dékpa Forest Reserve". Additional studies were undertaken to assess plant diversity, its value for flora conservation (Vroh et al., 2014). This initial survey allowed to record 358 plant species among which 30, including Cola lorougnonis, are classified as rare and threatened by IUCN (2015b) or with different levels of endemism according to White (1983), Aké-Assi (2001-2002), and Poorter et al. (2004).
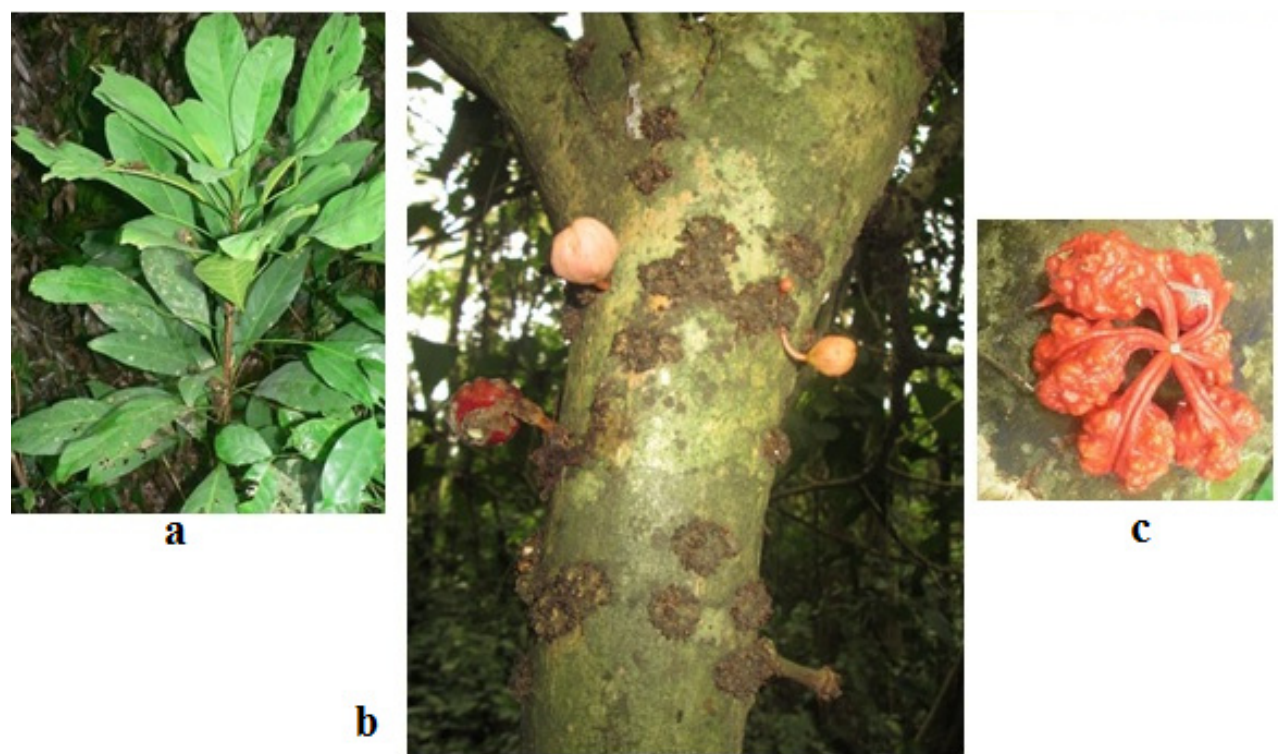

\section{$\mathbf{b}$}

$\mathbf{a}$ : sapling; $\mathbf{b}$ : mature stem; $\mathbf{c}:$ mature fruit

Figure 1. Photographic views of the primary target species Cola lorougnonis

While waiting for a legal status for conservation of Dékpa forest, we considered that these rare and endemic species, mainly Cola lorougnonis, are under the threat of farmers' permanent activities in Divo region. For the majority of these species, records have been reported in several areas of Côte d'Ivoire except for Cola lorougnonis. Only Divo region has been reported for this species. However, its distribution in Côte d'Ivoire or Divo region is not clearly defined. Accurate modelling of geographical distributions of Cola lorougnonis is crucial to various applications in ecology and conservation. This study analyzed suitable habitat models for Cola lorougnonis and compared to those of 20 others plant species. The main objective was to test geographic predictions for the focused species: Cola lorougnonis. Especially we characterized climatic factors that could explain the spatial distributions and modeled suitable habitats for Cola lorougnonis in natural ecosystem.

\section{Methods}

\subsection{Data Collection for Suitable Habitat Modelling}

\subsubsection{Environmental Variables}

The aim in modeling the habitat distribution, in the present study, is to suggest new sites for rare, endemic to West African forest or Upper Guinean forests, and endangered species. Species appear often to obey different suites of environmental variables at different spatial scales (Ortega-Huerta \& Peterson 2003). In other words, 
they may seek optimal suites of climatic conditions at relatively coarse conditions. For this study, we considered twenty environmental variables as potential predictors of the twenty one plants species habitat distribution. There were altitude and nineteen bioclimatic variables obtained from WorldClim dataset (http://www.worldclim.org/ bioclim.htm). These variables were chosen based on their biological relevance to plant species distributions and other habitat modelling studies (Kumar et al., 2006; Guisan et al., 2007, Pearson et al., 2007; Murienne et al., 2009). Bioclimatic variables concerned Temperature and precipitation data from 1950 to 2000.

\subsubsection{Target Species and Occurrence Data}

Initially 31 species with particular ecological status (endemism, rarity, threat) were recorded in Dékpa forest (Vroh et al., 2014; Vroh et al., 2015). We modelled habitats for only those $(\mathrm{N}=21$, Table 1) that are considered rare and endemic to Ivorian territory (GCi, Aké-Assi, 2001-2002), endemic species to Upper Guinea forests (HG, Poorter et al., 2004), and species endemic to West African forests also called West African Guineo-Congolian species (GCW; White, 1983).

Nine to fifty height occurrence records of these twenty one plants species were from national Herbarium of Côte d'Ivoire (Herbarium ivorensis UCJ) located in Centre National de Floristique (CNF) at University Félix Houphouët-Boigny. We used also data from the Herbarium of Centre Suisse de Recherche (CSRS) and the book "Catalogue des Plantes Vasculaires" (Aké-Assi, 2001-2002). We complemented our data, using those from Global Biodiversity Information Facility (GBIF) on http://www.gbif.org/faq/datause.

\subsection{Data Analysis}

\subsubsection{Suitable Habitat Modeling Procedure}

Maximum entropy distribution or Maxent is a general-purpose method for characterizing probable distributions from incomplete information, and has recently been applied to model species distributions (Phillips et al., 2006; Abdou et al., 2016). This method has been found best among several many different modeling methods (Elith et al., 2006; Ortega-Huerta \& Peterson, 2008), and may remain effective despite small sample sizes (Hernandez et al., 2006; Pearson et al., 2007; Papes \& Gaubert, 2007; Wisz et al., 2008; Benito et al., 2009). This program is a good alternative to those requiring both presence and absence records because reliable absence data are rarely available in poorly sampled regions, or for species that are easily missed during surveys (Ferrier et al., 2002; Engler et al., 2004). Also this method has been found to perform best among many different modelling methods (Elith et al., 2006; Ortega-Huerta \& Peterson, 2008), and may remain effective despite small sample sizes (Hernandez et al., 2006; Pearson et al., 2007; Papes \& Gaubert, 2007; Wisz et al., 2008; Benito et al., 2009) as we observed in our case study.

For this study, we used the freely available Maxent software, version 3.1 (http:// www.cs.princeton.edu/ $\sim$ schapire/maxent/), which generates an estimate of probability of presence of the species (varies from 0 to 1 ), where 0 being the lowest and 1 the highest probability. The entire occurrence records (Table 1) and the 20 environmental predictors were used in Maxent to model potential habitat distributions for the 21 rare plant species. The predictive performance of the model is assessed by testing or validation. Ideally an independent data set should be used for testing the model performance, however, in many cases, as in present study, this will not be available, a situation particular prevalent for threatened and endangered species.

Therefore, as authors did commonly, we used the approach that partition the data randomly into 'training' and 'test' sets, thus creating quasi-independent data for model testing (Fielding \& Bell, 1997; Guisan \& Hofer, 2003). However, this approach may not work with a small number of samples because the 'training' and 'test' datasets will be very small (Pearson et al., 2007). Therefore, we followed Pearson et al. (2007) and used a jackknife (also called 'leave-one-out') procedure, in which model performance is assessed based on its ability to predict the single locality that is excluded from the 'training' dataset.

We evaluated Maxent predictions using the area under the receiver-operating characteristic curve (AUC). The AUC scores are interpreted as reflecting the ability of the model to distinguish presence data from background data (Phillips et al., 2006) and is one of the most widely used methods to evaluate model performance (Franklin, 2009). AUC is a valid measure of relative model performance between models for the same species and study area (Elith et al., 2006). According to the different value of AUC, the models can be qualified as Excellent (AUC > 0.9); Good (0.8< AUC $\leq 0.9)$, Acceptable $(0.7<$ AUC $\leq 0.8)$, Poor $(0.6<$ AUC $\leq 0.7)$ or Invalid $(0.5<$ AUC $\leq$ 0.6) (Peterson et al., 2008; Hoffman et al., 2008). We use this classification to cluster the 21 target species according to the AUC value. 
Table 1. List of target species and the number of their records in Côte d'Ivoire

\begin{tabular}{lcc}
\hline Species names & Ecological status & Number of records \\
\hline Baphia bancoensis Aubrév. & GCi & 58 \\
Cola lorougnonis Aké Assi * & HG, GCi & 9 \\
Combretum grandiflorum G. Don & GCW & 57 \\
Dalbergia oblongifolia G. Don & GCW & 30 \\
Dialium aubrevillei Pellegr. & GCW & 26 \\
Diospyros heudelotii Hiern & GCW & 16 \\
Diospyros vignei F. White & GCW & 54 \\
Drypetes singroboensis Aké Assi & GCi & 23 \\
Eugenia leonensis Engl. \& v. Brehm. & GCW & 18 \\
Hippocratea vignei Hoyle & GCW & 27 \\
Milicia regia (A. Chev.) C. C. Berg. & HG & 37 \\
Millettia lane-poolei Dunn & GCW & 35 \\
Platysepalum hirsutum (Dunn) Hepper & GCW & 26 \\
Rinorea oblongifolia (C.H. Wright) Marquand ex Chipp & HG & 44 \\
Sabicea discolor Stapf. & HG & 25 \\
Salacia lateritia N. Hallé & HG & 35 \\
Triclisia patens Oliv. & GCW & 47 \\
Turrea heterophylla Sm. & HG & 51 \\
Urera keayi Letouzey & HG & 30 \\
Xylia evansii Hutch. & GCW & 13 \\
Xylopia villosa Chipp & HG & 32
\end{tabular}

Legend. GCi, GCW and HG = endemic respectively of Côte d'Ivoire, West African forest and Upper Guinean forests. *Although endemic to Upper Guinea, the species is never recorded outside Ivorian territory.

\subsubsection{Suitable Habitat Comparison}

For each species, the map of distribution in Côte d'Ivoire was drawn using the DIVA-GIS 7.5 software. The raster of potential distribution for each species generated by Maxent in ASCII format ( ${ }^{*}$.asc), was modified after their importation into DIVA-GIS (See Scheldeman \& van Zonneveld, 2012 for more details). The visualization was improved by adapting the legend proposed by default. We considered that the conditions of suitable habitat for each species are acceptable when at least $50 \%$ of these factors are present in an area.

We compared the suitable habitat areas of Cola lorougnonis (the main target species) to those of other rare species. This comparison allowed us to identify possible spatial (in geographical space) relationships among species. However if these spatial relationships exist, only experimental approaches can test the existence of a causal link (Connell 1983; Schoener 1983; Anderson et al., 2002; Rice et al., 2003).

Because Maxent determined the heuristic estimate of relative contributions of altitude and each climatic variable in each species distribution model, we performed a Principal Component Analysis (PCA) to reduce dimensionality and obtain a smaller number of species groups based on the percentage of contribution delivered by each variable, using R 3.2.3 software. PCA permitted the ordination of species according to environmental variable and confirmed which factors are responsible for similarities between the suitable habitat distribution (Urbina-Cardona \& Loyola, 2008). This test was performed only with the first two variables with the highest contributions in achieving suitable habitat distribution of different species. We also selected only species having an $\mathrm{AUC} \geq 0.9$. 


\section{Results and Discussion}

\subsection{Model Performance, Predictions and Suitable Potential Habitats of the Twenty One Species}

After the inventory in Dékpa forest, the geographic range of 21 rare plant species was estimated through the analysis of the outputs from the climatic models for Côte d'Ivoire. These species have all high conservation value: West African Guineo-Congolian (GCW) species which are endemic to West African forests (White, 1983), endemic species to Upper Guinean Forest (Poorter et al., 2004), and endemic species to Ivorian flora (Aké-Assi, 2001, 2002). Some other are also endangered or threatened species according to the red list of International Union for Conservation of Nature (IUCN, 2015).

Predictive accuracy (expressed as AUC values) values presided for three groups of species (Table 2). The first group concerned eleven (11) species that have their predictive accuracy value between 0.9 and 1 (Table 2), meaning that most of the individual models had a good fit for these species. For these species, our results are considered excellent (Thuiller et al., 2003). The maximum values of AUC was 0.99 observed for Cola lorougnonis the main species which is rare, endanger and endemic in Côte d'Ivoire (IUCN, 1994; Vroh et al., 2014, Aké-Assi, 2001-2002). Cola lorougnonis is following by Milletia lane-poolei and Drypetes singroboensis with an AUC respectively equal to 0.98 and 0.96 .

The second group concerned height other species which have their AUC ranging from 0.81 to 0.89 (Table 2), which indicate that predictive quality of the models can be considered good. In this group, AUC for Diospyros vignei (0.89) is bigger than the other species; therefore, the model accuracy for prediction of Diospyros vignei is higher than other species (Table 2).

The third group concerned two species Eugenia leonensis and Dalbergia oblongifolia with respectively 0.78 and 0.76 value of AUC. For these two species, predictive model is considered acceptable (Haffman et al., 2008). We noted that any results concerned AUC value was neither bad none invalid. Hence, it is displayed that Maxent is very effective at determining potential habitat distribution for different species. The results revealed that the predicted potential distribution areas through Maxent almost always appear as over predicted in some area compared to the realized niche of the species. Because Maxent considers only niche-based presence data, it estimates the species fundamental niche (different from occupied niche) rather than realized niche (Kumar \& Stohlgren, 2009; Yang et al., 2013). This study is based only on a set of existing data. These results could be better with additional data collected in the field, as it has been done by Abdou et al. (2016) about niche modeling of Prosopis africana in Niger and others authors (Hirzel \& Guisan, 2002).

\subsection{Suitable Habitats Comparison between these Twenty One Rare Species in Côte d'Ivoire}

In this study, Maxent model outputs resulted in twenty one different maps, each corresponding to a species (Figures 2,3 , and 4). These maps show the mean probability of occurrence for each characterizing species in Côte d'Ivoire. According to (Phillips et al., 2006; Elith et al., 2011), lower values of AUC as are related to Diospyros vignei, Combretum grandiflorum, Platysepalum hirsutum, Triclisia patens, Xylopia villosa, Turrea heterophylla, Diospyros heudelotii, Hippocratea vignei, Eugenia leonensis, and Dalbergia oblongifolia, could be considered a sinantropic species. There are species with a wider ecological niche than the other characterizing species. Those species could be found in different types of forest habitats in the South, west and East of Côte d'Ivoire. Species with wider distributions often encompass a greater range of environmental conditions (Gaston, 2003) and thus may be harder to model, especially when the number of training points is limited (see Thuiller et al., 2004).

In contrary, the eleven species with AUC ranging from 0.9 and 0.99 are very restricted to climatic variables (Ardestani et al., 2015) in Côte d'Ivoire. Among these eleven species, observing maps of distribution, we noted that Millettia lane-poolei, Urera keayi, Sabicea discolour, Milicia regia, Rinorea oblongifolia, Salacia lateritia, Baphia bancoensis, Xylia evansii and Dialium aubrevillei have their suitable habitats which are clearly different from that of Cola lorougnonis and Drypetes singroboensis. These nine species grow most in rainforest zone in South, South-East, South-West and West Côte d'Ivoire.

However, these maps show while Drypetes singroboensis is currently present in large areas in Côte d'Ivoire comparing to Cola lorougnonis, these two species can have the same focused area. This study shows that moist semi-deciduous forest is the main habitat for these two species in Côte d'Ivoire. Results confirmed that Cola lorougnonis and Drypetes singroboensis are very rare species and Cola lorougnonis was recorded only in Divo region as mentioned by Aké-Assi (1998) in Côte d'Ivoire. The same author have also mentioned that Drypetes singroboensis is a species which, although common in places, is found only in dry forest areas in southern Ghana and in moist semi-deciduous forest between the rivers Bandama and N'Zi in Côte d'Ivoire. This study confirmed the location zone for Drypetes singoboensis in Côte d'Ivoire. In Côte d'Ivoire, this species was recently also 
recorded in Oumé region (Sangne et al., 2008) and in Kokumbo region (Kpangui et al., 2015). This species was also recorded in Guinean forest in the Forêt Classée du Pic de Fon, Simandou Range, located in forest and savannah transitional zone (Holié \& Delamou, 2004). We think that this species has a large distribution than Cola lorougnonis which is very confined in Divo region. It is also most confined to the dry forest than Cola lorougnonis is confined to moist semi-deciduous forest.

Table 2. Estimation of relative contributions of the environmental variables to the Maxent model

\begin{tabular}{|c|c|c|c|}
\hline Class of AUC & Species / AUC & Factors with high contribution (\%) & Optimum values \\
\hline \multirow{22}{*}{ Excellent } & \multirow{2}{*}{ Cola lorougnonis / 0.99} & Bio $18=$ Precipitation of warmest season $(51.6 \%)$ & $\geq 400$ \\
\hline & & Bio $19=$ Precipitation of coldest season $(27.7 \%)$ & $\leq 200$ \\
\hline & \multirow{2}{*}{ Millettia lane-poolei / 0.98} & Bio $6=$ Minimum temperature of coldest month $(51.4 \%)$ & $\geq 22$ \\
\hline & & Bio $9=$ Mean temperature of driest season $(13 \%)$ & $27 \geq$ \\
\hline & \multirow{2}{*}{ Drypetes singroboensis / 0.96} & Bio $6=$ Minimum temperature of coldest month $(57.7 \%)$ & $\geq 22$ \\
\hline & & Bio $19=$ Precipitation of coldest season (17.5) & $\leq 100$ \\
\hline & \multirow{2}{*}{ Urera keayi / 0.95} & Bio $13=$ Precipitation of wettest period $(38.1 \%)$ & $\geq 550$ \\
\hline & & Bio $6=$ Minimum temperature of coldest month $(30 \%)$ & $\geq 22$ \\
\hline & \multirow{2}{*}{ Sabicea discolor / 0.94} & Bio $17=$ Precipitation of driest season $(79.2 \%)$ & $\geq 125$ \\
\hline & & Bio 12 = Annual precipitation $(8 \%)$ & $\geq 2250$ \\
\hline & \multirow{2}{*}{ Milicia regia / 0.93} & Bio $13=$ Precipitation of wettest period $(68.5 \%)$ & $\geq 550$ \\
\hline & & Bio $19=$ Precipitation of coldest season $(19 \%)$ & $200-250$ \\
\hline & \multirow{2}{*}{ Rinorea oblongifolia / 0.91} & Bio $14=$ Precipitation of driest period $(66.3 \%)$ & $\geq 20$ \\
\hline & & Bio $6=$ Minimum temperature of coldest month $(17.2 \%)$ & $20-25$ \\
\hline & \multirow{2}{*}{ Salacia lateritia / 0.91} & Bio $14=$ Precipitation of driest period $(44.3 \%)$ & $\geq 25$ \\
\hline & & Bio $5=$ Maximum temperature of warmest month $(25.6 \%)$ & $150-300$ \\
\hline & \multirow{2}{*}{ Baphia bancoensis / 0.90} & Bio $14=$ Precipitation of driest period $(58 \%)$ & $\geq 20$ \\
\hline & & Bio $13=$ Precipitation of wettest period $(27.2 \%)$ & $\geq 550$ \\
\hline & \multirow{2}{*}{ Xylia evansii / 0.90} & Bio $18=$ Precipitation of warmest season $(33.4 \%)$ & $\geq 500$ \\
\hline & & Bio $9=$ Mean temperature of driest season (31.3\%) & $\geq 22$ \\
\hline & \multirow{2}{*}{ Dialium aubrevillei / 0.90} & Bio $14=$ Precipitation of driest period $(69 \%)$ & $\geq 25$ \\
\hline & & Bio 2 = Mean diurnal range $(18.9 \%)$ & $70-80$ \\
\hline \multirow{16}{*}{ Good } & \multirow{2}{*}{ Diospyros vignei / 0.89} & Bio $6=$ Minimum temperature of coldest month $(70.4 \%)$ & $\geq 22$ \\
\hline & & Bio $13=$ Precipitation of wettest period $(14.8 \%)$ & $450-500$ \\
\hline & \multirow{2}{*}{ Combretum grandiflorum / 0.88} & Bio $5=$ Maximum temperature of warmest month $(27 \%)$ & $\leq 35$ \\
\hline & & Bio $14=$ Precipitation of driest period $(26.4 \%)$ & $\leq 10$ \\
\hline & \multirow{2}{*}{ Platysepalum hirsutum / 0.88} & Bio $14=$ Precipitation of driest period $(73 \%)$ & $\geq 85$ \\
\hline & & Bio $18=$ Precipitation of warmest season $(8.1 \%)$ & $\geq 500$ \\
\hline & \multirow{2}{*}{ Triclisia patens / 0.87} & Bio $13=$ Precipitation of wettest period $(49.3 \%)$ & $\geq 580$ \\
\hline & & Bio $14=$ Precipitation of driest period $(14.7 \%)$ & $\geq 25$ \\
\hline & \multirow{2}{*}{ Xylopia villosa / 0.87} & Bio $17=$ Precipitation of driest season $(43.2 \%)$ & $\geq 310$ \\
\hline & & Bio $13=$ Precipitation of wettest period $(26.6 \%)$ & $\geq 580$ \\
\hline & \multirow{2}{*}{ Turrea heterophylla / 0.87} & Bio $6=$ Minimum temperature of coldest month $(36.7 \%)$ & $\geq 225$ \\
\hline & & Bio $13=$ Precipitation of wettest period $(34.8 \%)$ & $\geq 580$ \\
\hline & \multirow{2}{*}{ Diospyros heudelotii / 0.86} & Bio $6=$ Minimum temperature of coldest month ( $46.6 \%)$ & $\geq 220$ \\
\hline & & Bio $18=$ Precipitation of warmest season $(17.3 \%)$ & $\geq 500$ \\
\hline & \multirow{2}{*}{ Hippocratea vignei / 0.81} & Bio $6=$ Minimum temperature of coldest month $(50.8 \%)$ & $\geq 220$ \\
\hline & & Bio $17=$ Precipitation of driest season $(26.3 \%)$ & $\geq 310$ \\
\hline \multirow{4}{*}{ Acceptable } & \multirow{2}{*}{ Eugenia leonensis / 0.78} & Bio $11=$ Mean temperature of coldest season $(59.6 \%)$ & $\geq 250$ \\
\hline & & Bio $8=$ Mean temperature of wettest season $(17.5 \%)$ & $\geq 275$ \\
\hline & \multirow{2}{*}{ Dalbergia oblongifolia / 0.76} & Bio $17=$ Precipitation of driest season $(64.7 \%)$ & $\geq 320$ \\
\hline & & Bio $7=$ Temperature annual range $(17.8 \%)$ & $\leq 25$ \\
\hline
\end{tabular}




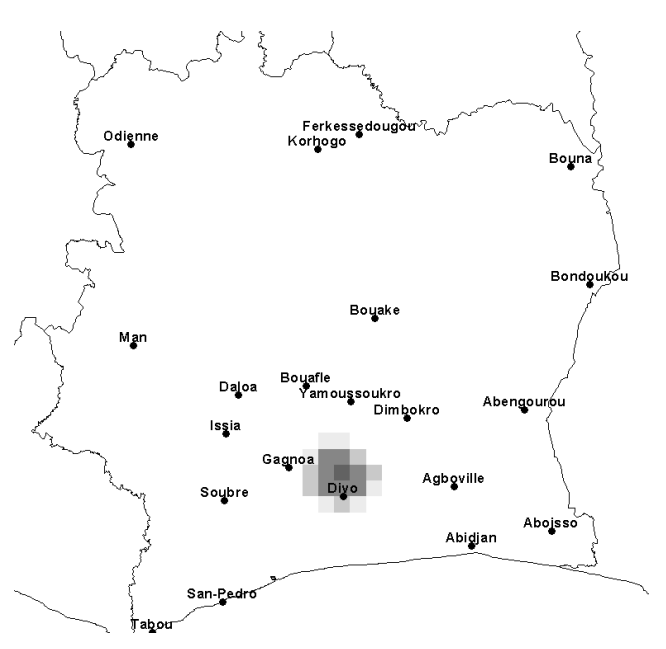

Cola lorougnonis

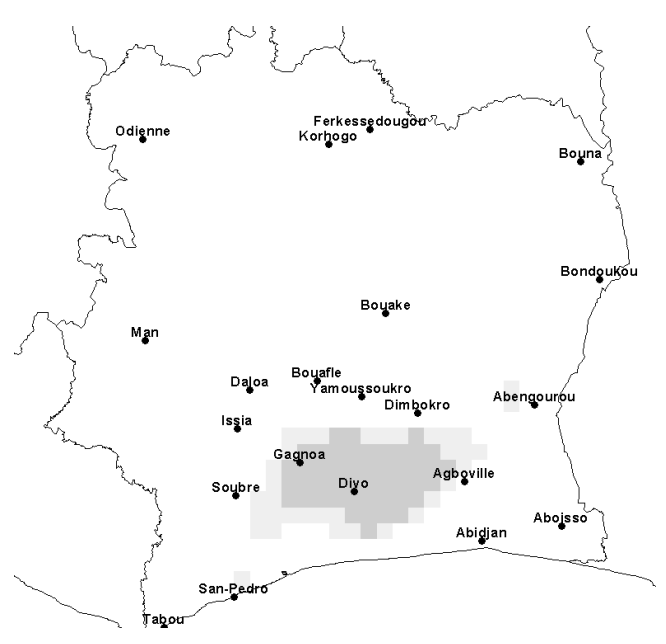

Drypetes singroboensis

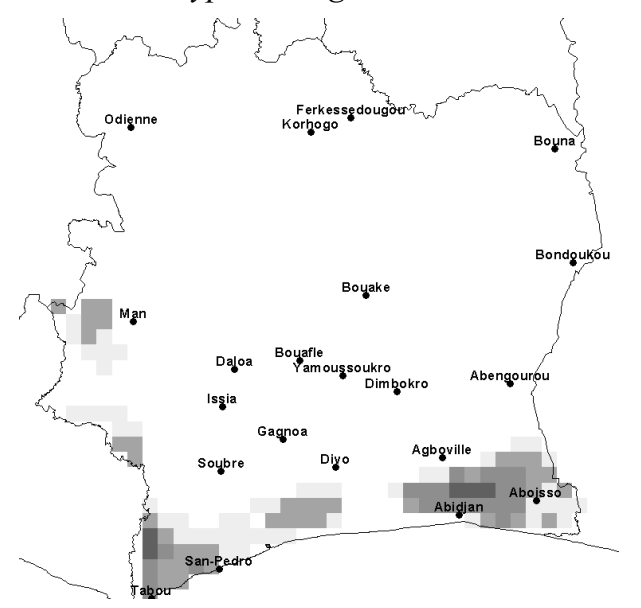

Sabicea discolor

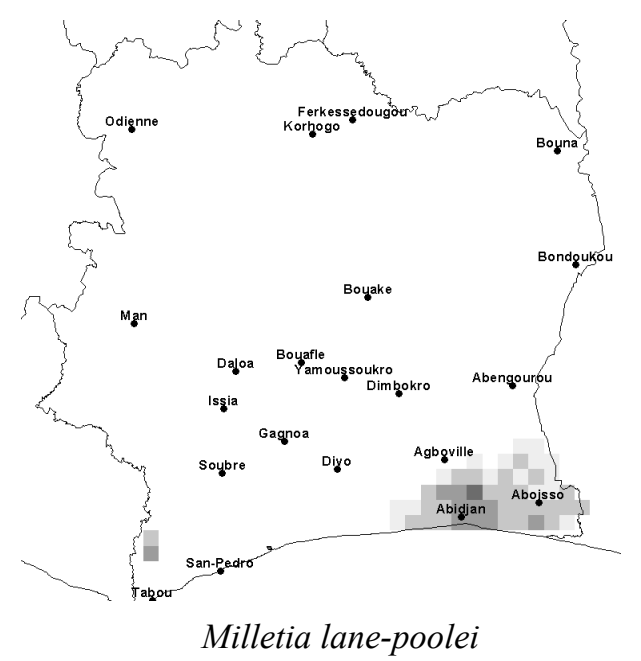

Milletia lane-poolei

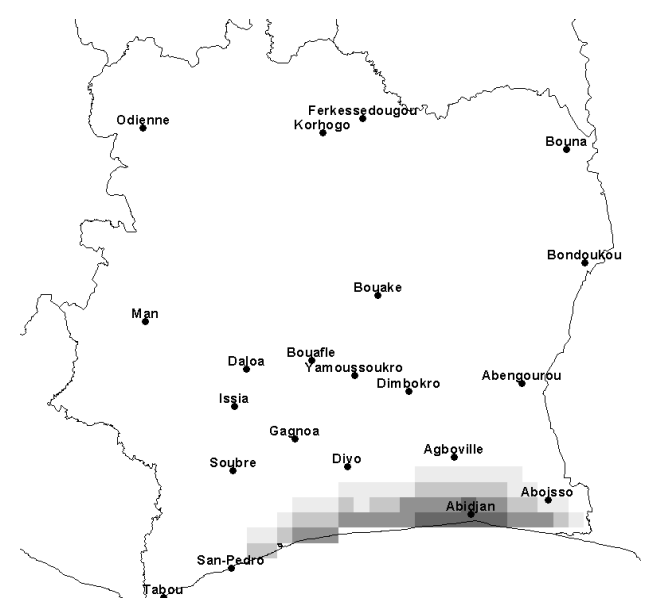

Legend:

Maxent model:

Bold colours

show areas with better predicted conditions.

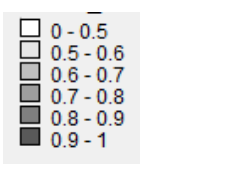

\section{Urera keayi}

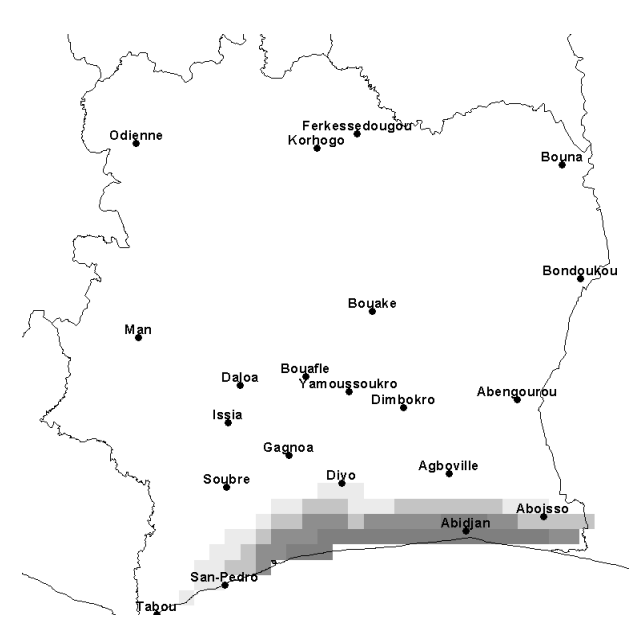

Milicia regia

Figure 2. Maps of the Maxent model for species in excellent AUC Class 

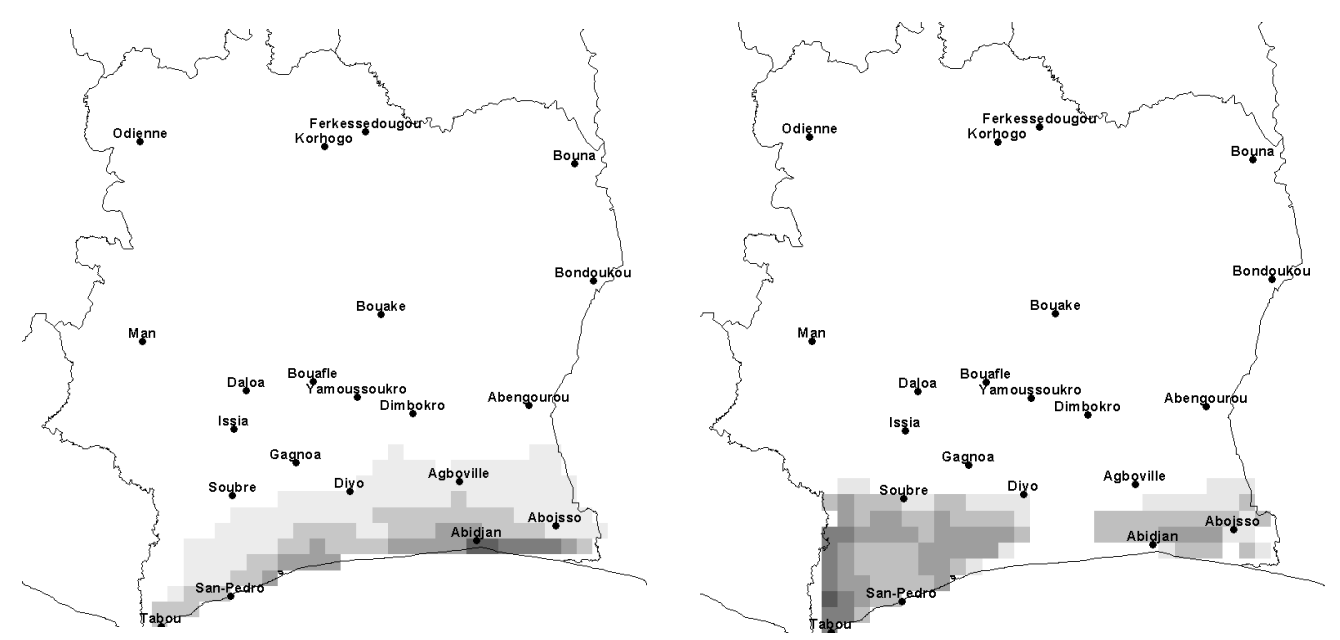

Rinorea oblongifolia

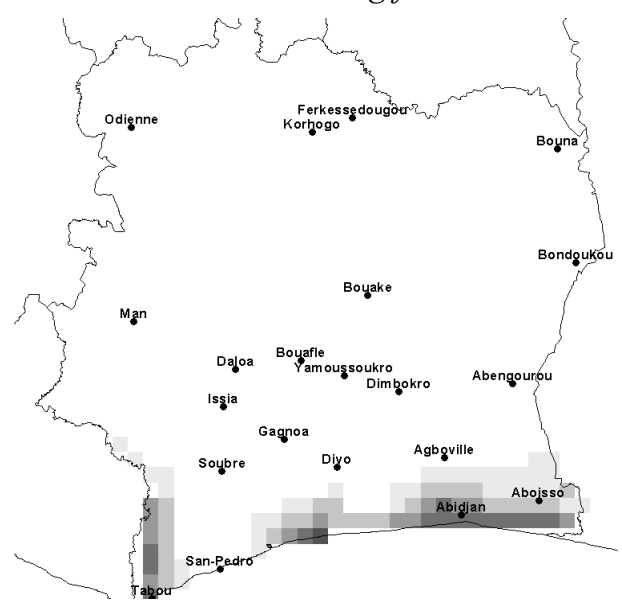

Salacia lateritia

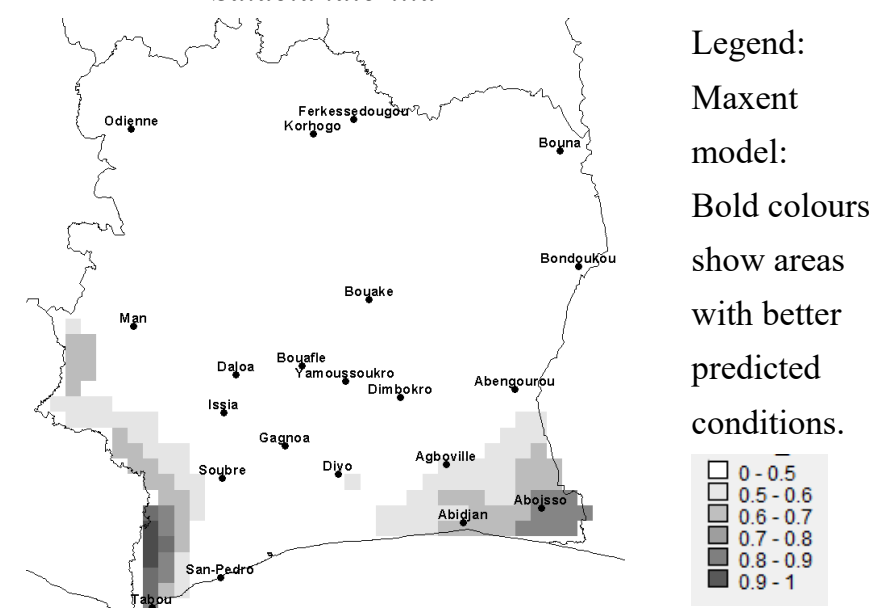

Baphia bancoensis

Xylia evansii

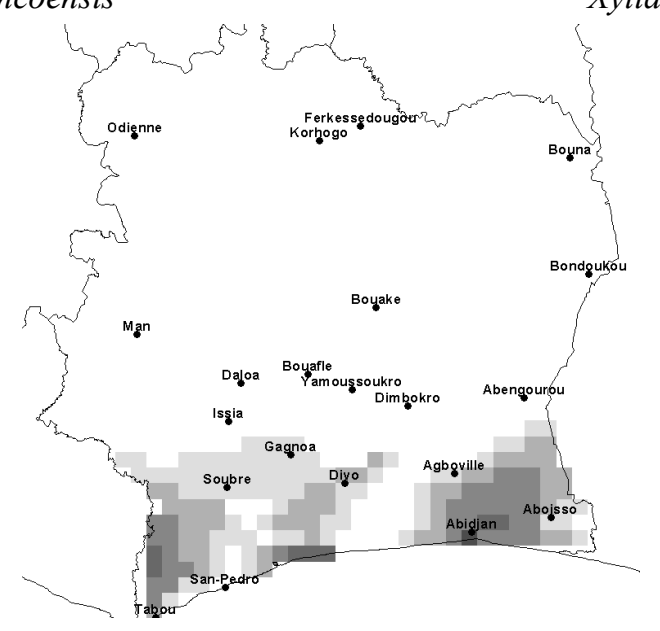

Dialium aubrevillei

Figure 2. Maps of the Maxent model for species in excellent AUC Class (continuation) 


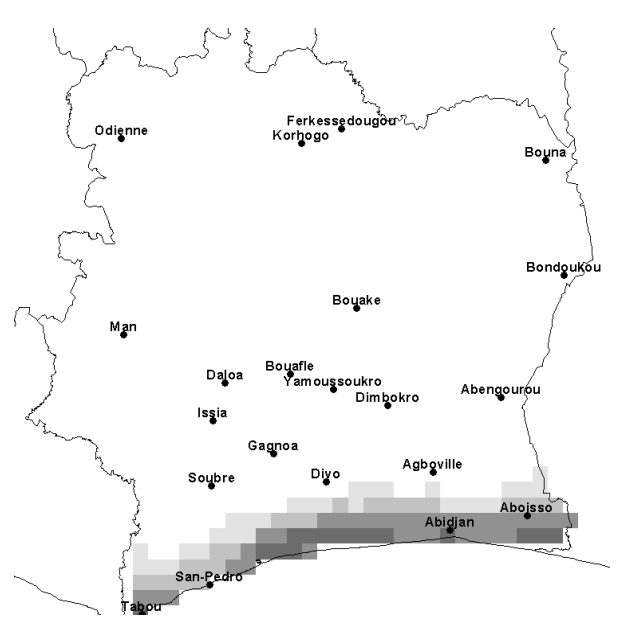

Diospyros vignei

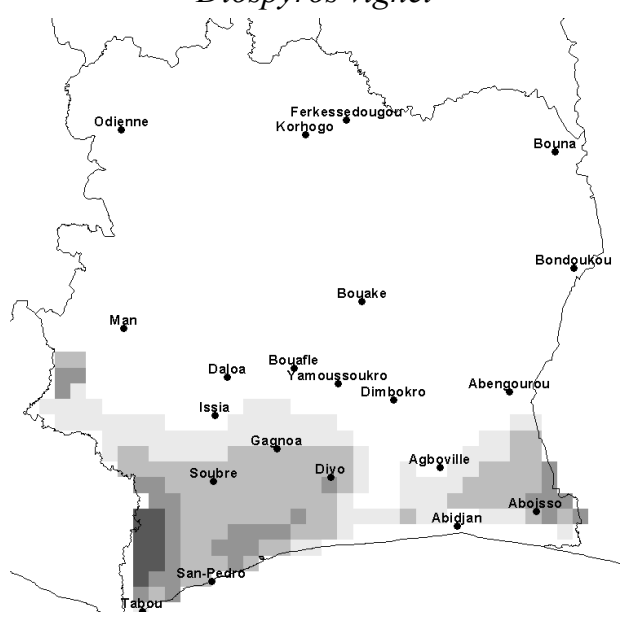

Platysepalum hirsutum

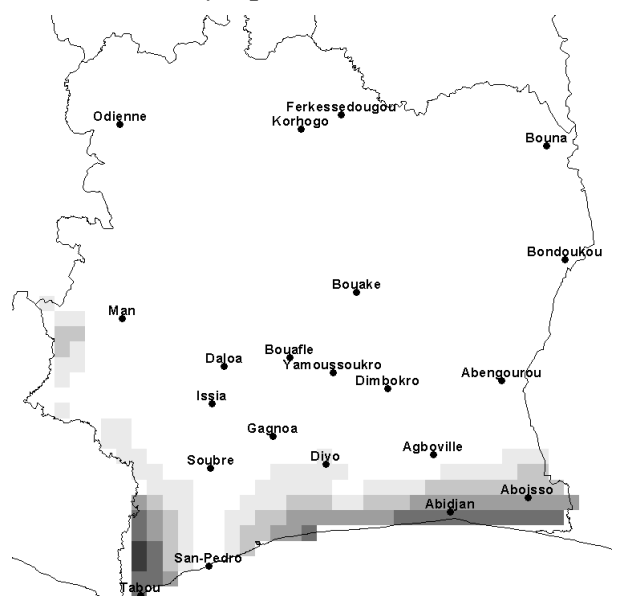

Xylopia villosa

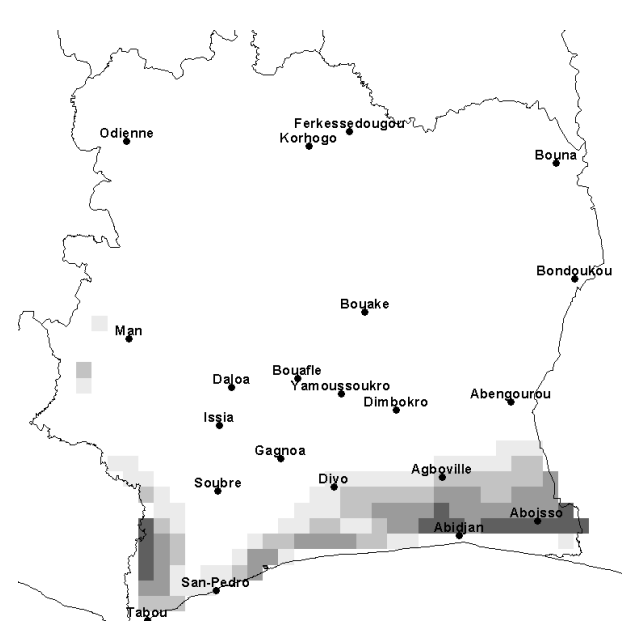

Combretum grandiflorum

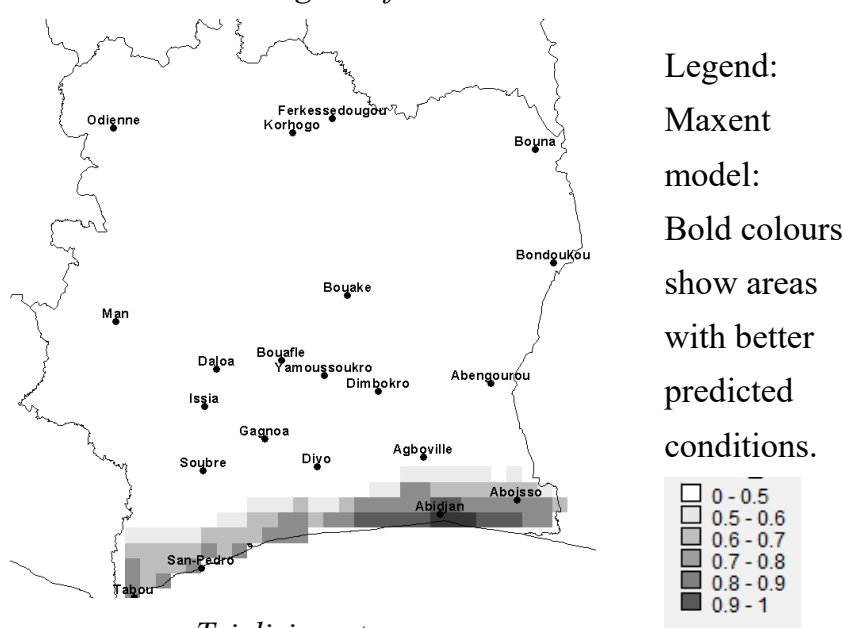

Triclisia patens

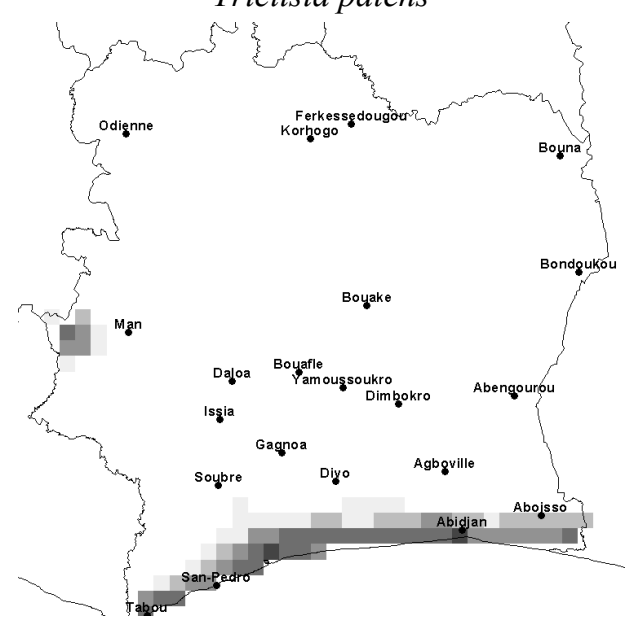

Turrea heterophylla

Figure 3. Maps of the Maxent model for species in good AUC Class 


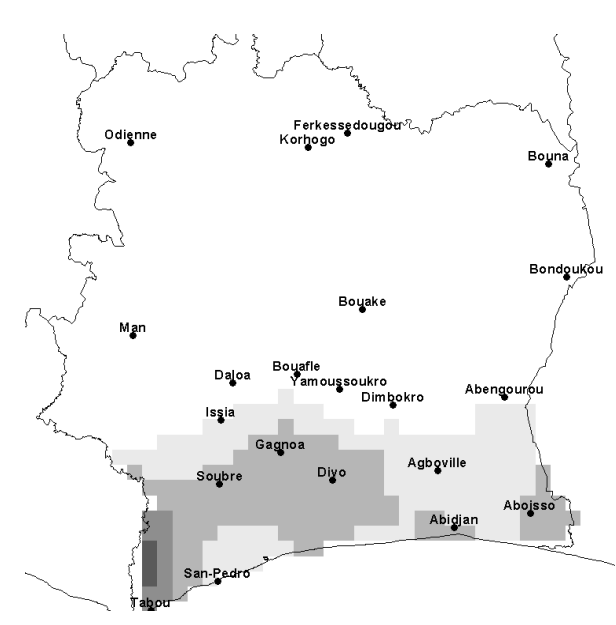

Diospyros heudelotii

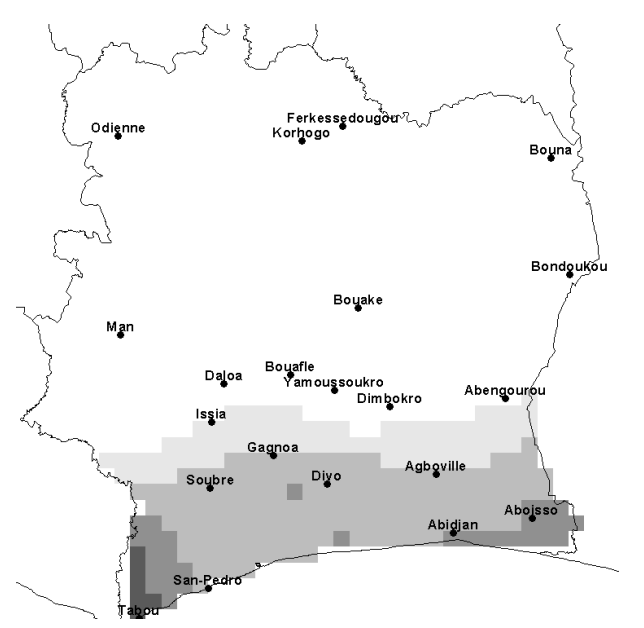

Hippocratea vignei
Legend:

Maxent model:

Bold colours show areas with better predicted conditions.

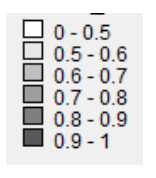

Figure 3. Maps of the Maxent model for species in good AUC Class (continuation)

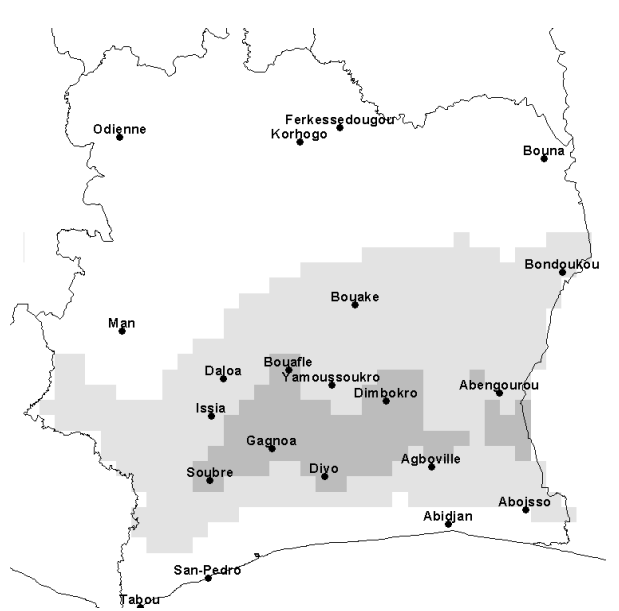

Eugenia leonensis

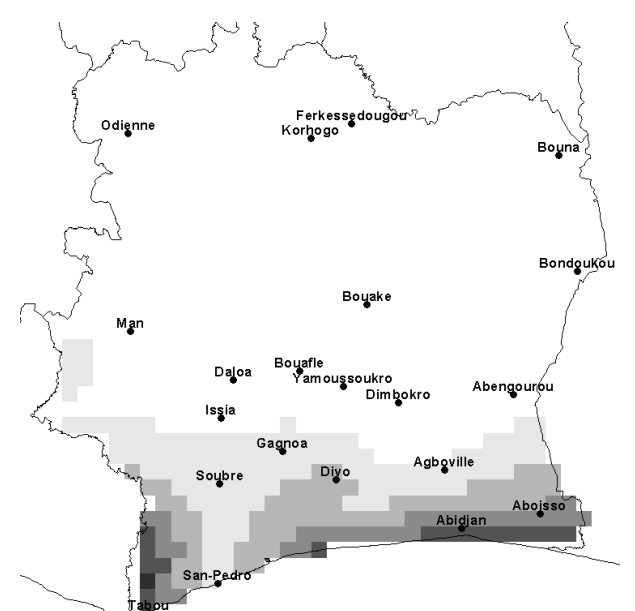

Dalbergia oblongifolia
Legend:

Maxent model:

Bold colours

show areas with better predicted conditions.

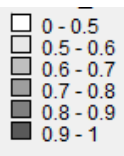

Figure 4. Maps of the Maxent model for species in acceptable AUC Class

Figure 5 shows relationships between predicted conditions for Cola lorougnonis and Drypetes singroboensis in Côte d'Ivoire. We can notice on this Figure 5, that when $70 \%$ of predicted conditions for Drypetes singoboensis are realized in an area, those of Cola lorougnonis has reached more than $80 \%$. But, in areas with better predicted conditions for Drypetes singroboensis (more than $70 \%$ of predicted conditions), we are beyond predicted conditions for Cola lorougnonis and therefore its presence declines.

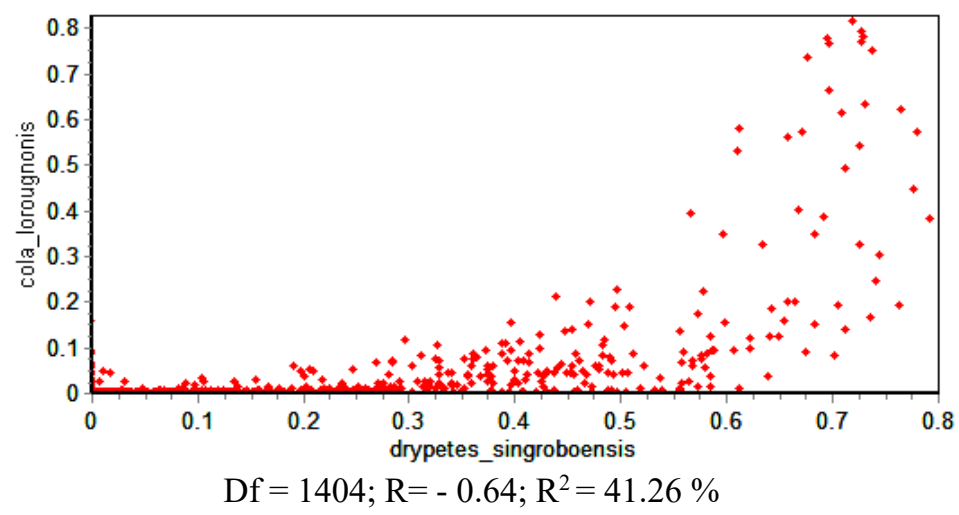

Figure 5. Relationships between predicted conditions of Cola lorougnonis and Drypetes singroboensis 
These results show that a simple way of comparing niches with habitat suitability models is to model the habitat of different species independently in the same area and compare their characteristics (Hirzel \& Lay, 2008). This may be done either in geographical space by comparing the predicted distributions of species (Anderson et al., 2002; Rice et al., 2003), or in the environmental space by measuring niche similarities (e.g. Reutter et al., 2003; Chefaoui et al., 2005). These correlative approaches can only show spatial relationships among species. Only an experimental approach (e.g. Connell, 1983; Schoener, 1983) can test the existence of a causal link. However, the spatial scales involved generally prevent experimentation. For Drypetes singroboensis and Cola lorougnonis, declines in habitat have been severe, mainly because of the effects of human population growth, agriculture but also because of fires (Aké-Assi, 1998). Distribution maps of these two species can help in planning land use management around their existing populations, discovering new populations, showing top-priority survey areas or setting priorities to restore their natural habitats for more effective conservation (Kumar \& Stohlgren, 2009). These areas would play a key role in situ conservation area for the species and could also be used for reintroduction, rehabilitation and recovery of the two species in the landscape. We also noted that area for these two species is focused in Divo region where Dékpa forest is managed (Vroh et al., 2014). These potential distribution maps can be used by range manager for correct response to changing ecosystems in Divo area with focus in Dékpa forest. Visual comparisons of the actual records data of the two species (Aké-Assi, 1998; Aké-Assi, 2001-2002, Poorter et al., 2004) in Côte d'Ivoire will represent also an excellent agreement. These kind of results have permitted to suggest the conservation plan for some West African target species such as Chrysophyllum albidum in Bénin (Gbesso et al., 2013) and Prosopis africana in Niger (Abdou et al., 2016). This is a general situation under the tropics according to Cayuela et al. (2009) who have investigated the problems and potentialities of species distribution modeling as a tool for conservation planning and policy development and implementation in tropical regions. These authors concluded that species distribution modeling have a great potential to support biodiversity conservation in the tropics, by supporting the development of conservation strategies and plans, identifying knowledge gaps, and providing a tool to examine the potential impacts of environmental change.

\subsection{Climatic Variable Ranges for the Distribution of Cola Lorougnonis and Drypetes Singroboensis}

For Cola lorougnonis, the Maxent model's internal jackknife test of factor importance showed that the environmental variable with highest gain when used in isolation is Precipitation of warmest season (Bio18; 51.6\% of contributions), which therefore appears to have the most useful information by itself. The environmental variable that decreases the gain the most when it is omitted is the Precipitation of coldest season (Bio19; $27.7 \%$ of contributions), which therefore appears to have the most information that isn't present in the other variables (Figure 6 and Table 2). Cola lorougnonis is distributed in ranges Bio $18 \geq 400 \mathrm{~mm}$ and Bio19 $\leq 200 \mathrm{~mm}$ (Table 2).

For Drypetes singroboensis, the environmental variable with highest gain when used in isolation is Minimum temperature of coldest month (Bio6; $57.7 \%$ of variations) which therefore appears to have the most useful information by itself. The environmental variable that decreases the gain the most when it is omitted is annual precipitation (Bio12; $8.6 \%$ of variations), which therefore appears to have the most information that isn't present in the other variables (Figure 6 and Table 2). Drypetes singroboensis has high occurrence probability in the areas with Bio6 $\geq 22{ }^{\circ} \mathrm{C}$ and Bio $12 \leq 500 \mathrm{~mm}$.

These results demonstrated biological tolerances and habitat preferences for both Cola lorougnonis and Drypetes singroboensis species (Ardestani et al., 2015). The application of a jackknife evaluation procedure allowed the confirmation of the importance of these variables. Specifically, the annual precipitation was confirmed as the variable that contributed the most to the model for Drypetes singroboensis (found only in dry forest areas in southern Ghana and Guinea, also in moist semi-deciduous forest) and Cola lorougnonis found only in moist semi-deciduous forest (See Kouamé \& Zoro, 2010 for maps of vegetation in Côte d'Ivoire). According to Guillaumet and Adjanohoun (1971) and Mangenot (1955) the climate of these areas has two main seasons: a dry season from November to February and a wet season from March to October. The annual rainfall is between 1,000 and $1,500 \mathrm{~mm}$ and the average is $1235.4 \mathrm{~mm}$. This rainfall is more favorable to Cola lorougnonis than Drypetes singroboensis (Bio12 $\leq 500 \mathrm{~mm}$ ). The maximum value of annual rainfall $(1,500 \mathrm{~mm})$ correspond to the warmest period in this area and that is favorable to Cola lorougnonis. During the coldest season, the rainfall ranging from 12 to $90 \mathrm{~mm}$; that is also favorable to Cola lorougnonis (Bio19 $\leq 200 \mathrm{~mm}$ ). The coldest months are December and January. Temperature varies from 10 to $38^{\circ} \mathrm{C}$ and annual average is $26^{\circ} \mathrm{C}$ (Estrucan ressources Côte d'Ivoire, 2008). Overall, these results highlight a larger contribution of features related to extreme value of both Precipitation of warmest season and Precipitation of coldest season for Cola lorougnonis. The precipitation regime during warm and cold season is in determining the climatic range of this species. 

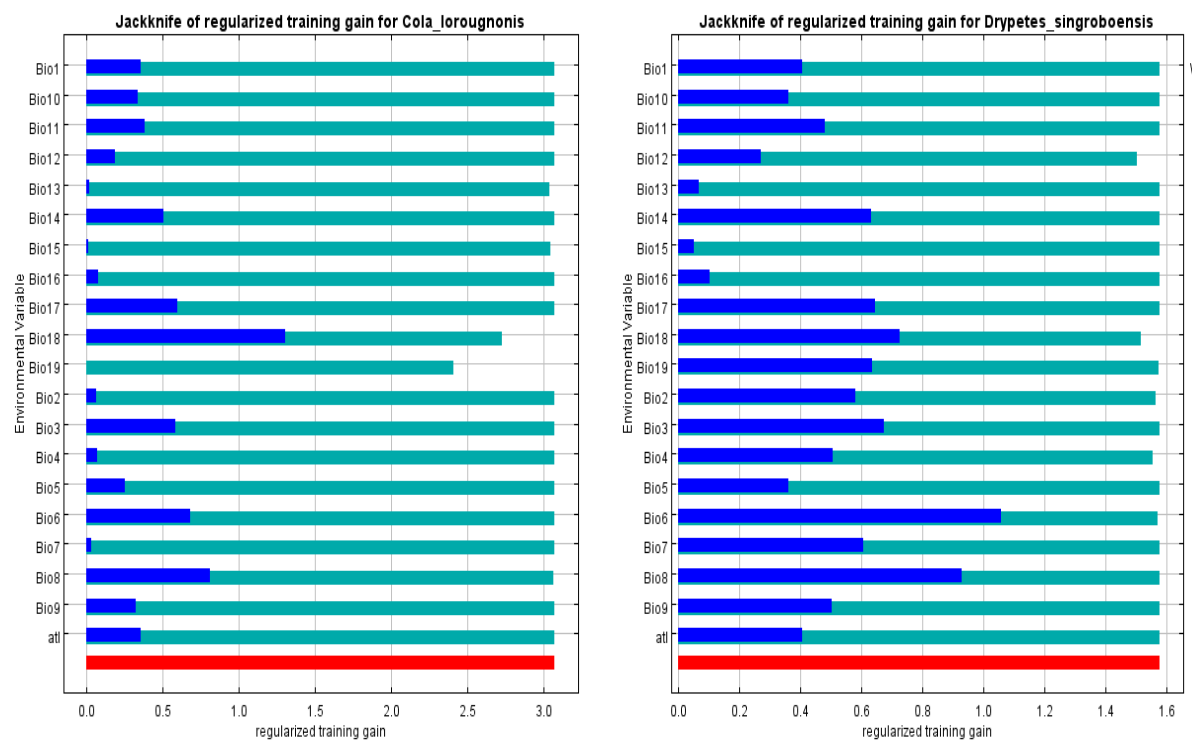

Figure 6. Jackknife tests of variable importance for Cola lorougnonis and Drypetes singroboensis

Legend: Green: without variable, Blue: with only variable, Red: with all variables
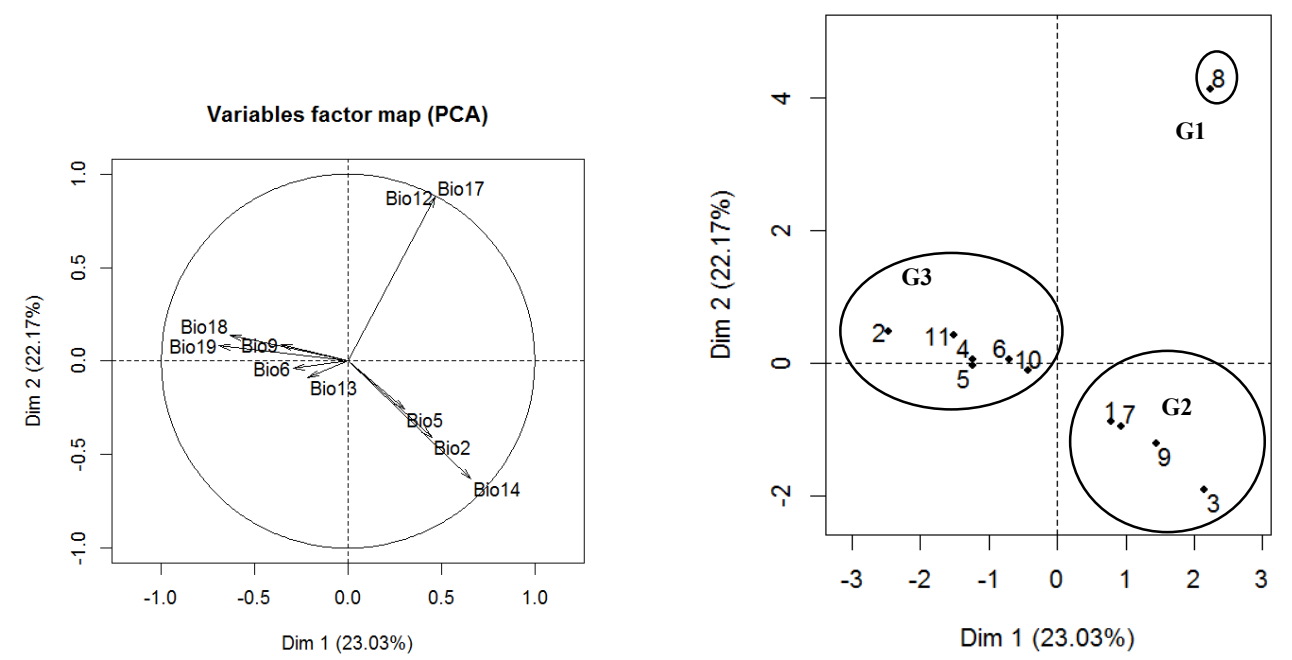
1 Baphia bancoensis
2 Cola lorougnonis
3 Dialium aubrevillei
4 Drypetes singroboensis
5 Milicia regia
6 Millettia lane-poolei

7 Rinorea oblongifolia

8 Sabicea discolor

9 Salacia lateritia

10 Urera keayi

11 Xylia evansii

Figure 7. Relationships between main variables and species with excellent predicted conditions

For each species with excellent model distribution in Maxent $(\mathrm{N}=11)$, we use the two main environmental factors to show relationships between them and climatic variables (Figure 7). The PCA maps reflect an isolation gradient of the suitable habitat. It allows us to discriminate three groups of species according to their suitable habitats isolation. Indeed Sabicea discolor which forms the group 1 (G1), is the only one of 11 species to have a 
continuous distribution in forest areas from East to West in Côte d'Ivoire. Thus, this species might least climatic variables demanding, comparing to other species. It is more suited to a wider variety of environments. Suitable habitat for this species can be limited only by Bio12 and Bio17 (see Table 2 for limits of these variables). In group 2 (G2), there are species that have less continuous distribution compared to that of Sabicea discolor. These species are more climatic variable demanding than Sabicea discolor and their potential habitats are limited by Bio2, Bio5 and Bio14 (see Table 2 for limits of these variables).

Finally Group 3 (G3) represents species which potential habitats are increasingly isolated: Cola lorougnonis and Drypetes singroboensis. The position of Cola lorougnonis in this group shows that this species is the most sensitive to climate parameters used in this study (Figure 7). Species in this group are sensitive to changes in following climatic variables (according to the order of importance): Bio18, Bio19, Bio9, Bio6 and Bio13. The limit values of these variables are also in the Table 2 .

Generally, the environmental conditions are optimal where the species is most frequently found (Guisan et al., 2000; Guisan, 2003). PCA results show that, overall, the most suitable areas were predicted to occur in all the territory of Côte d'Ivoire, in agreement with the known occurrences for study species. For Cola lorougnonis and Drypetes singroboensis, accordingly, in the case of gradually observed in this study, directionally changing environmental conditions, their species are condemned either to track their environment across space or to go extinct (Pease et al., 1989; Gimaret-Carpentier et al., 1998).

\subsection{Policy Brief Implication for Conservation}

Rare species are growing as one of the main issues of concern in the effort to conserve biodiversity worldwide, since these species are assumed to undergo higher risk of extinction. Rare species are characterized by restricted geographic ranges, habitat specialization or small population sizes. Their distribution datasets usually have small numbers of observations, often gathered over long periods of time and of limited spatial accuracy, and lack valid absences.

According to our study, Cola lorougnonis and Drypetes singroboensis are two endemic and rare species at national and international levels. Assessments of conservation status at the species level are generally performed using the International Union for Conservation of Nature (IUCN) Red List criteria. In the first publication in 1994, we found Cola lorougnonis and Drypetes singroboensis respectively in categories "Endangered" and "Vulnerable". Results show also the fragmentation or fluctuation in their geographic range; very restricted distribution. State of Côte d'Ivoire is obliged to undertake monitoring, assessment and reporting of conservation status for all habitats where these species can be found within the territory. Cola lorougnonis is considered "Endangered" because it has a small area of occurrence, certainly the number of individuals is very small. In recent years new populations, Cola lorougnonis and Drypetes singroboensis have been found, particularly in the Dékpa forest located in a gold perimeter. Despite the understanding of the mining company to protect this habitat, we think that the state of Côte d'Ivoire should do the best to facilitate the creation, conservation and protection of the reserve in Divo region.

The loss and degradation of natural habitats represents the most relevant single source of pressure on these two species locally and nationally, with recognized impacts in the group of plants analyzed in this study. These two species deserving so priority in conservation actions. Dékpa forest can be prioritized by state for conservation. That is an area where there is greatest need and where the payoff from conservation management measures would also be greatest.

In recent years, stimulated by an increasing awareness of the magnitude of human impacts on the environment, concerns for the conservation of some national park have become a popular issue. That is good for ecosystem conservation. But National Park or hotspots for different taxa do not coincide well with one another, that hotspots often miss rare species, and that major animal and plant groups could be lost by focusing too much attention to protected areas. We think that, there's a pressing need to develop research on the determinants for rare species distributions in order to understand and manage all biodiversity components, but also to meet society's aspirations.

We therefore envisage additional studies focusing on the survey areas identified in this study. It will check whether individuals or populations of these rare species are still living in remaining forests (community forests, sacred forests, cemeteries forests, etc.) or in protected in Divo region. If these studies demonstrate the existence of populations of these two species, conservation actions (habitat protection, awareness of local populations) will be necessary. 
Finally, we envisage to project present-day niche models onto future conditions of climate, as represented in large-scale climate models. That will permit to predict climate changes effects on populations of these species. These projections will allow us to know how they will change over the next few decades of evolving world climates.

\section{Acknowledgements}

The authors gratefully acknowledge UNU-INRA project team on 'Green Economy' towards the conduct of this research. We wish to thank Institut de Technologie Alimentaire (ITA, Dakar, Sénégal) for support and especially Dr Lat TOUNKARA, Beye CHEIKH, Nogaye CISSE for their support and comments. The contributions from anonymous reviewers are also duly appreciated.

\section{References}

Abdou, L., Diouf, A., Inoussa, M. M., Mamoudou, B. M., Illiassou, S. A., \& Mahamane, A. (2016). Modeling the Geographic Distribution of Prosopis africana (G. and Perr.) Taub. in Niger. Environment and Natural Resources Research, 6(2), 136-144. http://dx.doi.org/10.5539/enrr.v6n2p136

Aké-Assi, L. (1998). Drypetes singroboensis. The IUCN Red List of Threatened Species 1998: e.T32207A968 6336. http://dx.doi.org/10.2305/IUCN.UK.1998.

Aké-Assi, L. (2001). Flore de la Côte d'Ivoire 1, catalogue, systématique, biogéographie et écologie. Genève, Suisse : Conservatoire et Jardin Botanique de Genève.

Aké-Assi, L. (2002). Flore de la Côte d'Ivoire 2, catalogue, systématique, biogéographie et écologie. Genève, Suisse : Conservatoire et Jardin Botanique de Genève.

Anderson, R. P., Peterson, A. T., \& Gomez-Laverde, M. (2002). Using niche-based GIS modeling to test geographic predictions of competitive exclusion and competitive release in South American pocket mice. OIKOS, 98, 3-16. http://dx.doi.org/10.1034/j.1600-0706.2002.t01-1-980116.x

Ardestani, G. E., Tarkesh, M., Bassiri, M., \& Vahabi, M. R. (2015). Potential habitat modeling for reintroduction of three native plant species in central Iran. Jounal of Arid Land, 7(3), 381-390. Retrieved from http://link.springer.com/article/10.1007/s40333-014-0050-4

Benito, B. M., Martınez-Ortega, M. M., Munoz, L. M., Lorite, J., \& Penas, J. (2009). Assessing extinction-risk of endangered plants using species distribution models: a case study of habitat depletion caused by the spread of greenhouses. Biodiversity and Conservation. http://dx.doi.org/10.1007/s10531-009-9604-8.

Cayuela, L., Golicher, D. J., Newton, A. C., Kolb, M., de Alburquerque, F. S., Arets, E. J. M. M., Alkemade J. R. M., \& Pérez, A. M. (2009). Species distribution modeling in the tropics: problems, potentialities, and the role of biological data for effective species conservation. Tropical Conservation Science, 2(3), 319-352. www.tropicalconservationscience.org

Chefaoui, R. M., Hortal, J., \& Lobo, J. M. (2005). Potential distribution modelling, niche characterization and conservation status assessment using GIS tools: a case study of Iberian Copris species. Biological Conservation, 122, 327-338. http://www.sciencedirect.com/science/article/pii/S000632070400374X

Connell, J. H. (1983). On the prevalence and relative importance of interspecific competition - evidence from field experiments. The American Naturalist, 122(5), 661-696. http://www.jstor.org/stable/2460847

Elith, J., Graham, C. H., Anderson, R. P., Dudik, M., Ferrier, S., \& Zimmermann, N. E. (2006). Novel methods improve prediction of species' distributions from occurrence data. Ecography, 29, 129-151. http://dx.doi.org/10.1111/j.2006.0906-7590.04596.x

Elith, J., Phillips, S. J., Hastie, T., Dudík, M., Chee, Y. E., \& Yates, C. J. (2011). A statistical explanation of MaxEnt for ecologists. Divers. Distributions, 17, 43-57. http://dx.doi.org/10.1111/j.1472-4642.2010.00725.x

Engler, R., Guisan, A., \& Rechsteiner, L. (2004). An improved approach for predicting the distribution of rare and endangered species from occurrence and pseudo-absence data. J. Appl. Ecol., 41, 263-274. http://www2.unil.ch/biomapper/Download/Engler-JappEco-2004.pdf

Estrucan ressources Côte d'Ivoire. (2008). Projet de développement de la mine d'or d'Agbaou : Etude d'impacts environnemental. Rapport d'étude. Abidjan, Côte d'Ivoire.

Ferrier, S., Watson, G., Pearce, J., \& Drielsma, M. (2002). Extended statistical approaches to modeling spatial pattern in biodiversity: the north-east New South Wales experience. I. Species-level modeling. Biodiv. Conserv., 11, 2275 - 2307. http://labs.bio.unc.edu/Peet/courses/bio255_2003f/papers/ferrier_etal2002.pdf 
Fielding, A. H., \& Bell, J. F. (1997). A review of methods for the assessment of prediction errors in conservation presence/absence models. Environ. Conserv., 24, 38-49. http://dx.doi.org/10.1017/S0376892997000088

Franklin, J. (2009). Mapping Species Distributions: Spatial Inference and Prediction. Cambridge University Press, Cambridge, UK.

Gaston, K. J. (1996). Species richness: measure and measurement. Biodiversity: a biology of numbers and difference. In K. J. Gaston (Ed.), Blackwell Science (pp. 77-113). Oxford.

Gbesso, F. H. G., Tenté, B. H. A., Gouwakinnou, N. G., \& Sinsin, B. A. (2013). Influence des changements climatiques sur la distribution géographique de Chrysophyllum albidum G. Don (Sapotaceae) au Benin. Int. J. Biol. Chem. Sci., 7(5), 2007-2018. http://dx.doi.org/10.4314/ijbcs.v7i5.18

Ghazoul, J., \& Sheil, D. (2010). Tropical rain forest ecology, diversity, and conservation. Oxford University press.

Gimaret-Carpentier, C., Pelissier, R., Pascal, P. J., \& Houllier, F. (1998). Sampling strategies for the assessment of tree species diversity. J. Veg. Sci., 9, 161-172. http://pelissier.free.fr/pdf/1998_JVS.pdf

Graham, C. H., \& Hijmans, R. J. (2006). A comparison of methods for mapping species ranges and species richness. Glob. Ecol. Biogeogr., 15, 578 - 587. http://dx.doi.org/10.1111/j.1466-8238.2006.00257

Guillaumet, J. L., \& Adjanohoun, E. (1971). La végétation de la Cote d'Ivoire. In J.M. Avenard, E. Eldin, G. Girard, J. Sircoulon, P. Touchebeuf, J-L. Guillaumet, E. Adjanohoun \& A. Perraud (Ed.), Le milieu naturel de Côte d'Ivoire (Mémoires ORSTOM n ${ }^{\circ} 50, \mathrm{pp} 161-263$ ) Paris (France).

Guisan, A., \& Hofer, U. (2003). Predicting reptile distributions at the mesoscale: relation to climate and topography. J. Biogeogr., 30, 1233-1243. http://dx.doi.org/10.1046/j.1365-2699.2003.00914.x

Guisan, A., Graham, C. H., Elith, J., \& Huettmann, F. (2007). Sensitivity of predictive species distribution models to change in grain size. Divers. Distrib., 13, 332-340. http://dx.doi.org/10.1111/j.1472-4642.2007.00342.x

Hoffman, J. D., Narumalani, S., Mishra, D. R., Merani, P., \& Zilson, R. G. (2008). Predicting potential occurrence and spread of invasive plant species along the North Platte River, Nebraska. Invasive Plant Science and Management, 1, 359-367. http://dx.doi.org/10.1614/IPSM-07-048.1

Hernandez, P. A., Graham, C. H., Master, L. L., \& Albert, D. L. (2006). The effect of sample size and species characteristics on performance of different species distribution modeling methods. Ecography, 29, 773-785. http://dx.doi.org/10.1111/j.0906-7590.2006.04700.x

Hijmans, R. J., Cameron, S. E., Parra, J. L., Jones, P. G., \& Jarvis, A. (2005). Very high resolution interpolated climate surfaces for global land areas. International Journal of Climatology, 25, 1965-1978. http://dx.doi.org/10.1002/joc.1276

Hirzel, A., \& Guisan, A. (2002). Which is the optimal sampling strategy for habitat suitability modelling? Ecological Modelling, 157(2-3), 331-341. http://dx.doi.org/10.1016/S0304-3800(02)00203-X

Hirzel, A. H., \& Lay, G. L. (2008). Habitat suitability modelling and niche theory. Journal of Applied Ecology, 45, 1372-1381. http://dx.doi.org/10.1111/j.1365-2664.2008.01524.x

Holié, J-L., \& Delamou, N. L. (2004). A rapid botanical study of the Forêt Classée du Pic de Fon, Guinea. In J. McCullough (Ed). A Rapid Biological Assessment of the Forêt Classée du Pic de Fon, Simandou Range, South-eastern Republic of Guinea (pp 42-47), Guinea. Retrieved from https://library.conservation.org/ Published\%20Documents/2009/35\%20RAP\%20Bulletin.pdf

International Union for Conservation of Nature. (2015a). Biodiversity Offsets Policy: Draft for public consultation. iucn.org/offsets.

International Union for Conservation of Nature. (2015b). IUCN Red List of Threatened Species. Version 2015.1. Retrieved August 28, 2015 from www.iucnredlist.org

Kouamé, N. F., \& Zoro, B. I. A. (2010). Nouveau découpage de la zone de forêt dense humide de la Côte d'Ivoire. Sciences \& Nature, 7(2), 177-194. http://dx.doi.org/10.4314/scinat.v7i2.59962

Kpangui, K. B., Kouame, D., Gone Bi, Z. B., Vroh, B. T. A., Koffi, B. J. C., \& Adou Yao, C. Y. (2015). Typology of cocoa-based agroforestry systems in a forest-savannah transition zone: case study of Kokumbo (Centre, Côte d'Ivoire). Int. J. Agr., 6(3), 36-47. Retrieved from http://www.innspub.net/wp-content/ uploads/2015/03/IJAAR-V6No3-p36-47.pdf 
Kumar, S., \& Stohlgren, T. J. (2009). Maxen $\mathrm{t}$ modellin $\mathrm{g}$ for predict in $\mathrm{g}$ suit able $\mathrm{h}$ abit at for th reat en ed and endangered tree Canacomyrica monticola in New Caledonia. J. Ecol. Nat. Environ., 1, 094-098. Retrieved from https://www.fort.usgs.gov/products/sb/5824

Kumar, S., Stohlgren, T. J., \& Chong, G. W. (2006). Spatial heterogeneity influences native and nonnative plant species richness. Ecol., 87, 3186 - 3199. Retrieved from http://www.ncbi.nlm.nih.gov/pubmed/17249242

Mangenot, G. (1955). Etude sur les forêts des plaines et plateaux de la Côte d'Ivoire. Études éburnéennes, tome IV, 5-61.

Murienne, J., Guilbert, E., \& Grandcolas, P. (2009). Species' diversity in the New Caledonian endemic genera Cephalidiosus and Nobarnus Insecta: Heteroptera: Tingidae, an approach using phylogeny and species' distribution modelling. Bot. J. Linn. Soc., 97, 177-184. http://dx.doi.org/10.1111/j.1095-8312.2008.01184.x

Nix, H. A. (1986). A biogeographic analysis of Australian Elapid snakes. In R. Longmore (Ed.), Australian Flora and Fauna (Series 8: 4-15).

Ortega-Huerta, M. A., \& Peterson, A. T. (2003). Effects of geographic scale on analyzing associations between regional habitats and distribution patterns of Mexican birds. Anales del Instituto de Biologia, 74, 203-210. Retrieved from http://www.ejournal.unam.mx/zoo/74-02/zoo74207.pdf

Ortega-Huerta, M. A., \& Peterson, A. T. (2008). Modeling ecological niches and predicting geographic distributions: a test of six presence-only methods. Revista Mexicana De Biodiversidad, 79, 205-216. Retrieved from http://www.scielo.org.mx/pdf/rmbiodiv/v79n1/v79n1a17.pdf

Papes, M., \& Gaubert, P. (2007). Modelling ecological niches from low numbers of occurrences: assessment of the conservation status of poorly known viverrids (Mammalia, Carnivora) across two continents. Diversity and Distributions, 13, 890 - 902. http://dx.doi.org/10.1111/j.1472-4642.2007.00392.x

Parmentier, I., Malhi, Y., Senterre, B., Whittaker, R. J., Alonso, A., Balinga, M. P. B., ... \& Wöll, H. (2007). The odd man out? Might climate explain the lower tree a-diversity of African rain forests relative to Amazonian rain forests? J. Ecol., 95, 1058 - 1071. http://dx.doi.org/10.1111/j.1365-2745.2007.01273.x

Pearson, T. R. H., Brown, S., Birdsey, L., \& Richard, A. (2005). Measurement guidelines for the sequestration of forest carbon. Newtown Square, PA: U.S. Department of Agriculture, Forest Service, Northern Research Station. 42. http://www.nrs.fs.fed.us/pubs/gtr/gtr_nrs18.pdf

Pearson, R. G., Raxworthy, C. J., Nakamura, M., \& Peterson, A. T. (2008). Predicting species distributions from small numbers of occurrence records: a test case using cryptic geckos in Madagascar. J. Biogeo., 34, 102-117. http://dx.doi.org/10.1111/j.1365-2699.2006.01594.x

Pease, C. M., Lande, R. \& Bull, J. J. (1989). A model of population growth, dispersal and evolution in a changing environment. Ecology, 70(6), 1657-1664. http://dx.doi.org/10.2307/1938100

Phillips, S. J., Anderson, R. P., \& Schapire, R. E. (2006). Maximum entropy modeling of species geographic distributions. Ecological modeling, 190, 231-259. Retrieved from http://www.cs.princeton.edu/ $\sim$ schapire/maxent

Poorter, L., Bongers, F., Kouamé, F. N., \& Hawthorne, W. D. (2004). Biodiversity of West African Forests: An Ecological Atlas of Woody Plant Species. CABI Publishing, Nederland, Pays-Bas.

Reutter, B. A., Helfer, V., Hirzel, A. H., \& Vogel, P. (2003). Modelling habitat suitability using museum collections: an example with three sympatric Apodemus species from the Alps. Journal of Biogeography, 30, 581 - 590. http://dx.doi.org/10.1046/j.1365-2699.2003.00855.x

Rice, N. H., Martínez-Meyer, E. \& Peterson, A. T. (2003). Ecological niche differentiation in the Aphelocoma jays: a phylogenetic perspective. Biological Journal of the Linnean Society, 80(3), 369 - 383. doi: 10.1046/j.1095-8312.2003.00242.x

Sangne, Y. C., Adou Yao, C. Y., \& N'Guessan, K. E. (2008). Transformations de la flore d'une forêt dense semi décidue : impact des activités humaines (centre ouest de la Côte d'Ivoire). Agro. Africaine, 20(1), 1-11. http://www.ajol.info/index.php/aga/article/viewFile/1731/629

Scheldeman, X., \& van Zonneveld, M. (2012). Manuel de formation à l'analyse spatiale de la diversité et de la distribution des plantes. Bioversity International, Rome, Italy.

Schoener, T. W. (1983). Field experiments on interspecific competition. The American Naturalist, 122(2), 240-285. Retrieved from http://www.jstor.org/stable/2461233 
Schroeder, J. M., Oke, D. O., Onyekwelu, J. C., \& Yirdaw, E. (2010). Secondary Forests in West Africa a Challenge and Opportunity for Management. Forests and society responding to global drivers of change, 335 - 353. http://www.academia.edu/15749075

Sheil, D., Puri, R. K., Basuki, I., van Heist, M., Wan, M., Liswanti, N., ... \& Wijaya, A. (2004). A la découverte de la biodiversité, de l'environnement et des perspectives des populations locales dans les paysages forestiers. Méthodes pour une étude pluridisciplinaire du paysage. Center for International Forestry Research.

Slik, F. J. W. S., Arroyo-Rodríguez, V., Aiba, S-I., Alvarez-Loayza, P., Alves, L. F., Balvanera, P., ... Zang, R. (2015). An estimate of the number of tropical tree species. Proc. Natl Acad. Sci. (Early Edition), 1-10. doi:10.1073/pnas. 1423147112

Thuiller, W., Vaydera, J., Pino, J., Sabate, S., Lavorel, S., \& Garcia, C. (2003). Large-scale environmental correlates of forest tree distributions in Catalonia (NE Spain). Global Ecology and Biogeography, 12, 313-325. http://dx.doi.org/10.1046/j.1466-822X.2003.00033.x

Thuiller, W., Araujo, M. B., Pearson, R. G., Whittaker, R. J., Brotons, L., \& Lavorel, S. (2004). Biodiversity conservation: uncertainty in predictions of extinction risk. Nature, 427, 145-148. http://dx.doi.org/ 10.1038 /nature 02716

Urbina-Cardona, J. N., \& Loyola, R. D. (2008). Applying niche-based models to predict endangered-hylid potential distributions: are neotropical protected areas effective enough? Journal - Tropical Conservation Science, 1(4), 417-445. Available online: www.tropicalconservationscience.org

Vroh, B. T. A., Ouattara, D., Tiébré, M. S., \& N'Guessan, K. E. (2015). Dékpa Botanical reserve, an example of innovation against land degradation and for conservation of plant diversity on mine sites (Côte d'Ivoire). In : B. Hubert \& M. Broin (Ed). Combating desertification/land degradation and drought for poverty reduction and sustainable development: the contribution of science, technology, traditional knowledge and practices (Agropolis International, pp: 210-211) Montpellier France.

Vroh, B. T. A., Tiébré, M. S., Ouattara, D., \& N'Guessan, K. E. (2014). La réserve forestière Dékpa d'Agbaou, un exemple de conservation de la diversité végétale sur les sites miniers de la Côte d'Ivoire. International Journal of Innovation and Applied Studies, 6(2), 162-171. Retrieved from http://www.ijias.issr-journals.org

White, F. (1983). The vegetation of Africa, a descriptive memoir to accompany the UNESCO/AETFAT/UNSO vegetation map of Africa. Natural Resources Research, 20, 1-356. Retrieved from http://unesdoc. unesco.org/images/0005/000580/058054eo.pdf

Wisz, M. S., Hijmans, R. J., Li, J., Peterson, A. T., Graham, C. H., \& Guisan, A. (2008). Effects of sample size on the performance of species distribution models. Diversity and Distributions. http://dx.doi.org/10. $1111 / \mathrm{j} .1472-4642.2008 .00482 . \mathrm{x}$

Yang, X. Q., Kushwaha, S. P. S., Saran, S., Xu, J., \& Roy, P. S. (2013). Maxent modeling for predicting the potential distribution of medicinal plant, Justicia adhatoda L. in Lesser Himalayan Foothills. Ecological Engineering, 51, 83-87. http://dx.doi.org/10.1016/j.ecoleng.2012.12.004

\section{Copyrights}

Copyright for this article is retained by the author(s), with first publication rights granted to the journal.

This is an open-access article distributed under the terms and conditions of the Creative Commons Attribution license (http://creativecommons.org/licenses/by/3.0/). 